International Journal of Agriculture and Environmental Research

ISSN: 2455-6939

Volume: 07, Issue: 03 "May-June 2021"

\title{
COST FACTOR ANALYSIS ALONG THE VEGETABLE SUPPLY CHAIN: SRI LANKA
}

\author{
*Kumari K.A.T.S., Dissanayake C.A.K., Herath M.M., \\ Somakanthan N., Wasantha P.G.L., Senawirathne S.H.R.L. \\ National Institute of Post Harvest Management, Jayanthi Mawatha, Anuradhapura, Sri Lanka. \\ "Corresponding Author \\ DOI: https://doi.org/10.51193/IJAER.2021.7303
}

\begin{abstract}
Sri Lanka is primarily an agricultural country. Agriculture plays a vital role in its terms of food safety, value addition, export earnings and employment. Various types of vegetables are grown in rural areas in small homesteads and large agricultural land for both consumption and commercial purposes. Commercial vegetable marketing system has an integrated supply chain system which influenced by different intermediaries and their activities to take vegetable from producers to ultimate consumers. The regulatory framework affects the food supply chain at all levels from the agricultural sector down to the retail sector. This causes to increase consumer prices of the commodities while having low price to the farmers. To overcome this issue, it is needed to identify the cost factors which are affected to the price increasing. Both primary and secondary data gathered for this research and descriptive and non-descriptive methods were used for the data analysis process. According to the study it shows that vegetable supply chains in Sri Lanka consist of at least six types of stake holder segments. At each step of a supply chain, the cost is added to the product and it leads to increase the price consequently. As it is an inefficient and long chain of market intermediary cause's price increase dramatically from farmer to consumer. The cost of production, cost of labor, packaging cost, post-harvest loss, and profit at each stage, commission, hauler fee, transport cost were significant cost factors along the supply chain. Indeed, cost of production, post-harvest losses and the profit at each level were highly contributing cost factors.
\end{abstract}

Keywords: Supply Chain, Vegetables, Cost Factors, Post-harvest losses, Price

\subsection{INTRODUCTION}

Agriculture is the driven factor of the Sri Lankan economy. It make $7.42 \%$ contribution to the GDP in 2019 (Economics, 2019). Most of the contribution to the GDP from agriculture sectors 
International Journal of Agriculture and Environmental Research

ISSN: 2455-6939

Volume: 07, Issue: 03 "May-June 2021"

comes from agricultural crops, including vegetables. Most of the rural areas in Sri Lanka supported to the growth of agriculture by directly/indirectly through vegetable cultivation. It is vital source of employment for the majority of rural Sri Lankan workforce. The vegetable industry is considered as the potential to develop backwards small farmers and consequently accelerate crop diversification in the paddy dominated non-plantation agriculture sector. Moreover, vegetables are considered as potential candidates for the diversification and commercialization of present farming context in Sri Lanka.

Agricultural commodities specially related to the vegetable and consumer food prices have been experienced in strong variations over the last decades, both upwards and downwards. This vegetable price volatility creates unpredictability in the market and poses fundamental food security risks for consumers and governments (Huchet-Bourdon, 2011, Matthews, 2010). Volatility also discourages needed investment in agriculture for development due to increased financial risks and uncertainty for producers and traders (Information, et al., 2012). Combined with long-term prospects of rising food prices, highlights the necessity to increase the efficiency of the food supply chain to ensure consumer food prices along with reducing post-harvest losses. The regulatory framework affects the food supply chain at all levels from the agricultural sector down to the retail sector. This causes to increase consumer prices of the commodities while having low price to the farmers.

As the industry, which occupied nearly 30 percent of total labor force in the country, it has impacted seriously on stabilizing food prices and the livelihood of farming community. It is a multifarious issue that related to agro climatic changes, natural hazards, consumer reactions, government policies and the global market changes. Hence, like the many developing countries, the successive governments of Sri Lanka have implemented various policy options to mitigate the issue. Even though this made a huge price fluctuation along the vegetable supply chain.

Consequently, it is a vital role to evaluate the price fluctuation and factors effecting to this issue along the vegetable supply chain. In order to overcome this issue, it is needed to identify what are the cost factors which will affect highly towards increasing the prices of each commodity and in what extend that are affecting to the final prices of each commodity. Thereby it is easy to reduce the price fluctuations and enhance the productivity of vegetable sector in the country while ensuring food security of the country.

Therefore, main concern of this study is to economically evaluation of pricing strategy for selected vegetables from farm gate to consumer while addressing the following specific objectives: identify the cost factors and their contribution towards the consumer price; determine key factors which affect the price transmission along the supply chain of the selected vegetables; identify potential factors to be controlled and increasing efficiency along the supply chain. 
International Journal of Agriculture and Environmental Research

ISSN: $2455-6939$

Volume: 07, Issue: 03 "May-June 2021"

\subsection{METHODOLOGY}

This study was targeted six major vegetable crops growing in Sri Lanka. These Vegetables were recorded the highest price fluctuations during the past consecutive years (HARTI, 2019). Vegetables grown in Sri Lanka are broadly divided into two groups, like up-country types and low-country types, supported the agro-ecological adaptability. During this study covered both up-country and low-country vegetables giving special focuses on Carrot, Beet Root, Capsicum, Beans, Brinjal and Pumpkin. Data were gathered through all supply chain actors covering 500 individuals as total population. Based on the highest production of each selected vegetables growing districts, farmers/producers were selected from Anuradhapura, Mathale, Norechole, Nuwara Eliya, Badulla and Jaffna. Among them Badulla and Nuwara Eliya were selected for Beans, Capsicum, Carrot and Beetroot production. Mathale district were selected for Beans production. Puttalam District was selected for Capsicum and Beetroot production. Jaffna district were selected for Carrot production. Anuradhapura Districts were selected for Pumpkin and Brinjal Production and Hambantota district were selected for pumpkin and Brinjal production.

Vegetable collectors were selected from Nuwara Eliya, Mathale, Puttalam, Jaffna, Anuradhapura and Hambanthota. Major whole seller markets were selected from Thabuttegama, Dambulla, Keppatipola and Manin Market. Finally, major consumer Districts data were gathered from Anuradhapura, Kurunegala, Kandy, Gampaha, and Colombo.

Primary data were collected directly through observation and questionnaire methods from an interview and group discussion of respondents. Secondary data were collected from agricultural statistics reports, Journals, thesis, research articles, annual reports, etc. The data that have been obtained by interview, questionnaire and observations were structured in an order. After completion of the data processing, the analysis was performed.

\subsection{RESULTS}

The results suggested that the vegetable supply chain in Sri Lanka consists of at least six types of stakeholder segments, which were identified as: producer, collector, transporter, wholesaler, and retailer. There are overlaps between collectors, transporters and wholesalers who are perform the role of transporters. In addition, overlapping was very common between retailers and wholesalers who performing both roles.Further it found that there are several forms of vegetable supply chains found in Sri Lanka. Each supply chain consists with at least three to four numbers of actors between farmers and consumers. The transporters, collectors and wholesales are link into the chain at different points.

The results shown that there are many other forms of vegetable supply chain such as large-scale farmers act as transporter and wholesaler at the same time. The small-scale farmers who act as a 
retailer as well. However, it was not practical to depict all these as flowcharts and hence only the most common have been depicted here. The various supply chains identified in this study illustrated in figure 01 .

Chain 1:

$\sum$ Farmer $\quad$ Retailer $\sum$ Consumer

Chain 2:

$\sum$ Farmer $\sum$ Collector $>$ Retailer $>$ Consumer

Chain 3:

$\sum$ Farmer $\sum$ Collector $\sum$ Transporter $>$ Wholesaler1 $>$ Retailer $\sum$ Consumer

Chain 4:

$\sum$ Farmer $>$ Collector $>$ Transporter $>$ Wholesaler $2>$ Retailer $>$ Consumer $\rangle$

Chain 5:

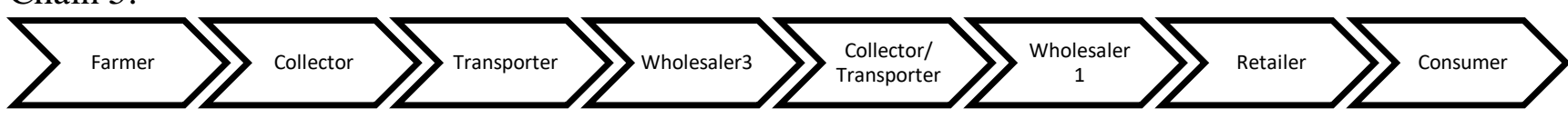

Chain 6:

$\sum$ Farmer $\sum$ Collector $\sum$ Processing Centers $>$ Consumer

Figure 01: The graphical illustration of different supply chains available in Sri Lankan vegetable market.

Wholesaler 1: Wholesaler in nearby town;

Wholesaler 2: Wholesaler in Economic centre in production area;

Wholesaler 3: Wholesaler in Economic centre in production area;

Collector 1: Private collection centre of a Supermarket/ Exporter;

Processing Centers: retail chain, company, factory for processing or packing plant of Exporter 
International Journal of Agriculture and Environmental Research

ISSN: 2455-6939

Volume: 07, Issue: 03 "May-June 2021"

\subsection{Cost and Price Movement in Supply Chain}

Table 1: Factors and their contribution towards final price

\begin{tabular}{|l|l|l|l|l|l|l|}
\hline & \multicolumn{5}{|c|}{ \% Contribution to the final price } \\
\cline { 2 - 7 } & Carrot & Beetroot & Beans & Capsicum & Brinjal & Pumpkin \\
\hline COP & 25.95 & 36.62 & 20.64 & 24.19 & 23.34 & 16.80 \\
\hline Labor & 4.53 & 7.65 & 3.55 & 2.69 & 7.02 & 10.07 \\
\hline Package & 0.99 & 1.45 & 0.74 & 1.66 & 2.34 & 2.53 \\
\hline PHL & 23.47 & 8.84 & 33.10 & 30.52 & 21.77 & 13.68 \\
\hline Profit & 33.52 & 33.01 & 33.69 & 33.28 & 32.58 & 43.57 \\
\hline Commission & 7.06 & 9.15 & 5.96 & 5.47 & 7.70 & 10.43 \\
\hline Hauler & 0.73 & 0.57 & 0.88 & 0.23 & 0.48 & 0.38 \\
\hline Transport & 3.36 & 1.99 & 1.08 & 1.79 & 2.65 & 2.05 \\
\hline Other & 0.40 & 0.72 & 0.35 & 0.18 & 1.37 & 0.49 \\
\hline
\end{tabular}

*COP: Cost of Production; PHL: Post Harvest Losses

Final price of vegetables are determined by the different cost involvements along the vegetable supply chain. At each level of vegetable supply chain cost were added to the final price of a product. So, the price of a product is consequently increasing due to the number of actors along the vegetable supply chain. As it is an inefficient and long chain with number of intermediaries ultimately creates a massive price gap between the farmer and consumer. With respect to that phenomenon, this study investigates the price at each level of most common vegetable supply chain and their proportionate contribution towards the final price of a product.

The existing vegetable marketing system consists of farmer, collector/ transporter, whole seller (local /divisional/regional), retailer and consumer. Product and cost flow start with the farmer and price is negotiating with collector/local whole seller. Farmer is the ultimate producer of a product and added production cost, profit, and post-harvest loss to determine the farm gate price. Then wholesalers/collectors negotiate with farmer and determine next level of price for the product, and it added with transport charges, profit, post-harvest loss, commission, hauler fee, and labour charges. Local whole seller to regional wholesaler and finally retailer determine the price for the product by considering their profit, labour cost, transportation, post-harvest loss and finally reached to the consumer. Ultimately, it creates long chain and high price gap create between farmer and consumer. 
Improper handling of vegetables and length of the chain causes for the most of post-harvest losses. To minimize the losses occurring at the wholesaler and retailer level they retain higher margins. After final processing retailer determine the price of vegetables by keeping very high level of profit margins along with cost of wastage. Due to the variation of time, cost, amount, and activities involve in the process, this price addition may be different.

Most significant cost factors along the vegetable supply chain were identified through secondary data and their final percentage contribution towards the vegetable price was identified (Table 01). It shows the significant factors which affect to the final price of each vegetable. These factors were cost of production, cost for the labour, packaging cost, post-harvest loss, profit at each stage, commission, hauler fee, transport and other cost as electricity cost, water Cost, telephone cost and building rent. Based on this data, final price of the vegetable is determined by,

Final price of vegetable $=$ Cost of production + Labourcost + Packaging cost + Post-Harvest Loss + Profit at each stage+ Commission+ Hauler fee+ Transport cost+ Other cost

\subsection{Price transmission analysis}

To understand the cost or value that is added at each stage by each stakeholder along the value chain, a price transfer analysis was conducted using the costs and margin figures collected from the sample survey.

\subsubsection{Carrot}

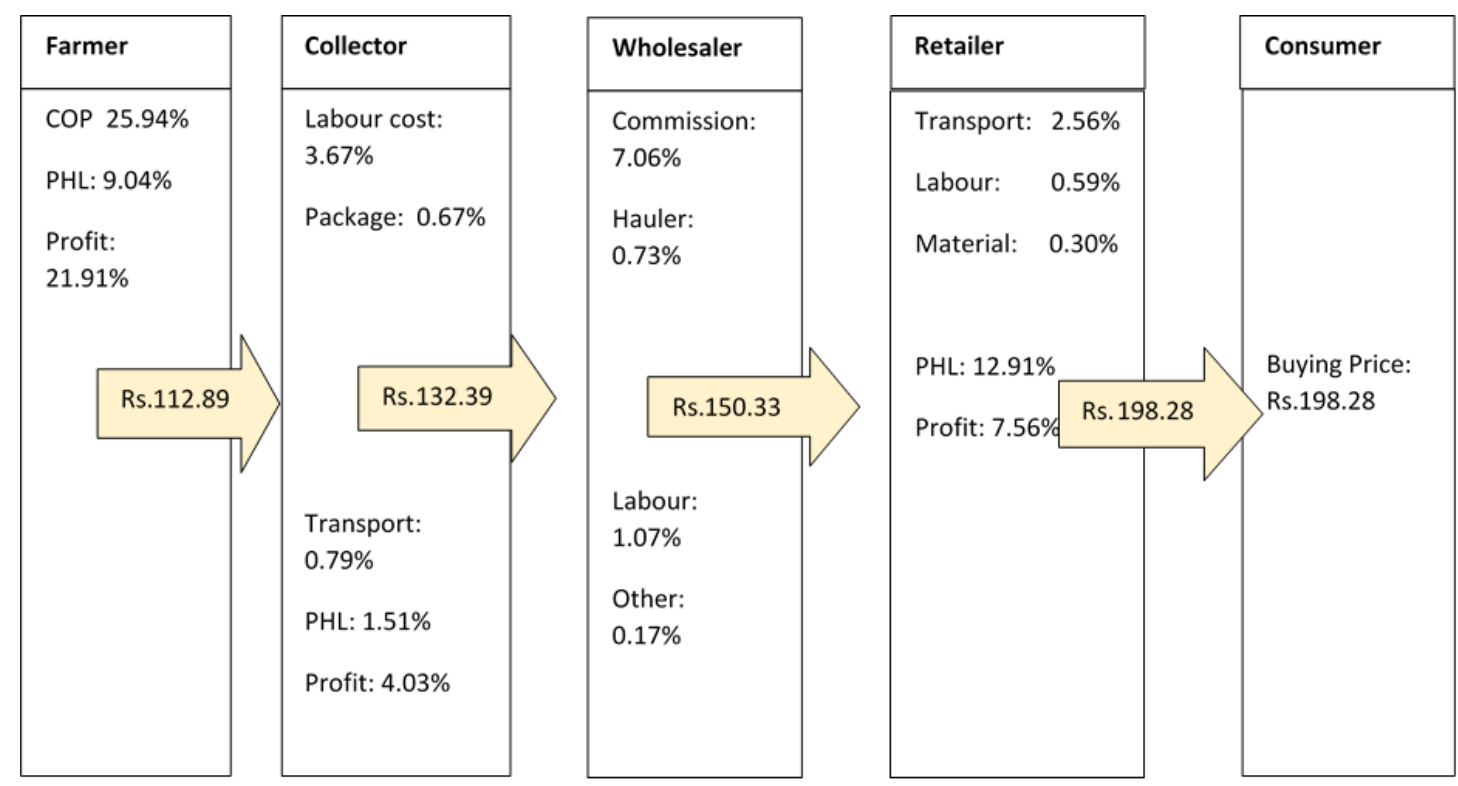

Figure 02: Final price formation of Carrot Crop 
The final price of carrot is determining via primary vegetable supply chain which exists farmer, collector, wholesaler and retailer (Figure 02). At the famer level production cost, cost for the post-harvest losses and the farmer's profit were added to the primary price of Carrot and it was about $56.9 \%$ by the final price (Rs.112.84). At the collector level, labor cost, material cost, transportation cost, post-harvest losses and collector's profit were added to the price of carrot and it was $9.85 \%$ by the total price (Rs.132.39), at the whole seller level 9.04\% added to the final price (Rs.150.33) and it was contributed by wholesaler commission, hauler fee, labor cost and other costs as building rent, electricity bill, water bill, telephone bills at the retailer level 24.18\% added to the final price (Rs.198.28) by the total cost of transport, labor, packing materials, post-harvest loses, other costs and retailer level profit.

\subsubsection{Beetroot}

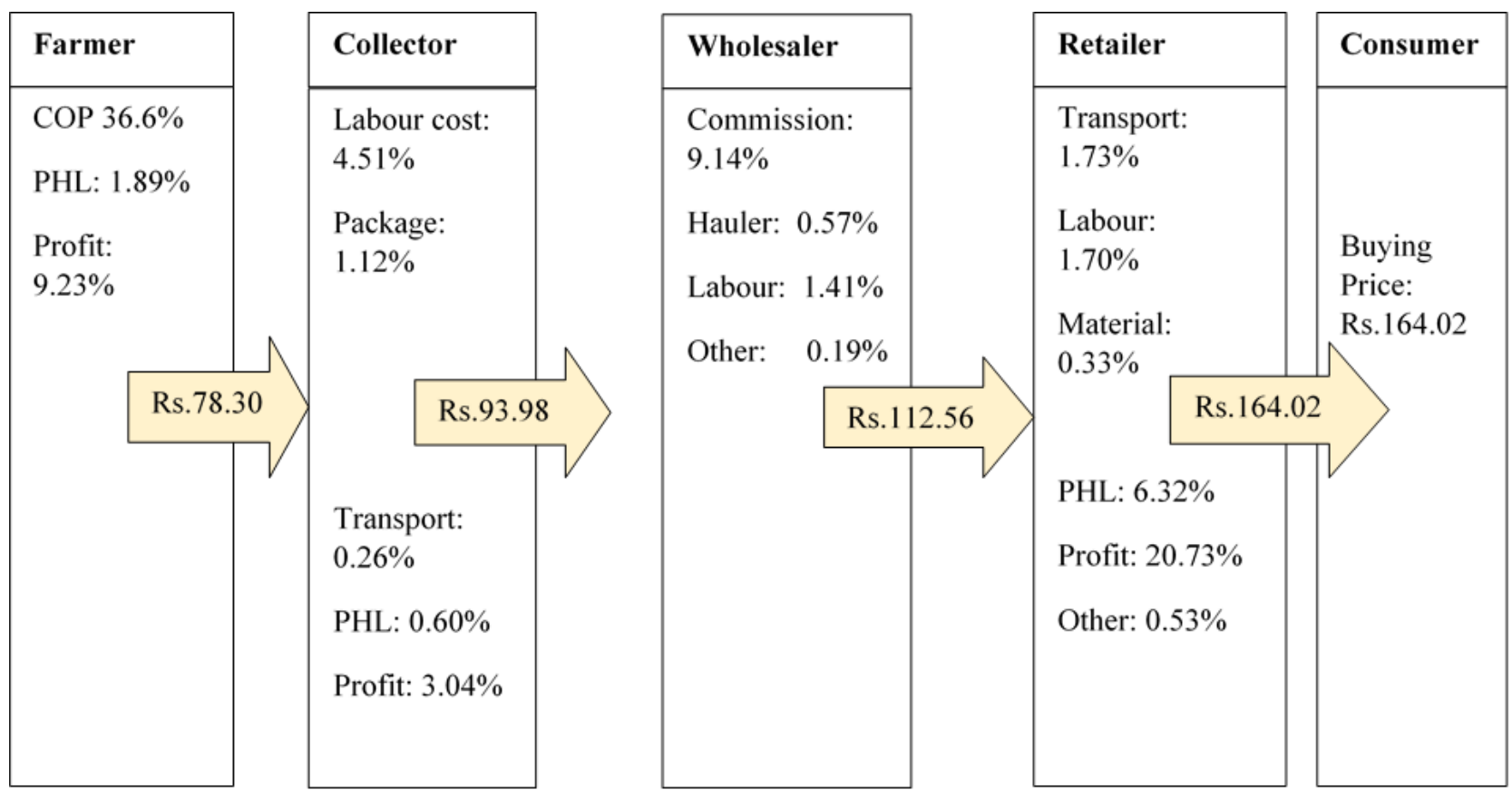

Figure 03: Final price formation of Beetroot Crop

The final price of Beetroot is determining via primary vegetable supply chain which exists farmer, collector, wholesaler, and retailer (Figure 03). At the famer level, production cost, cost for the post-harvest losses and the farmer's profit were added to the primary price of Beetroot and it was about $47.72 \%$ by the final price (Rs.78.30). At the collector level, labor cost, material cost, transportation cost, post-harvest losses and collector's profit were added to the price of Beetroot and it was $9.53 \%$ by the total price (Rs.93.98), at the whole seller level $11.31 \%$ added to the final price (Rs.112.56) and it was contributed by wholesaler commission, hauler fee, labor cost and other costs as building rent, electricity bill, water bill, telephone bills at the retailer 
level $31.34 \%$ added to the final price (Rs.164.02) by the total cost of transport, labor, packing materials, post-harvest loses, other costs and retailer level profit.

\subsubsection{Capsicum}

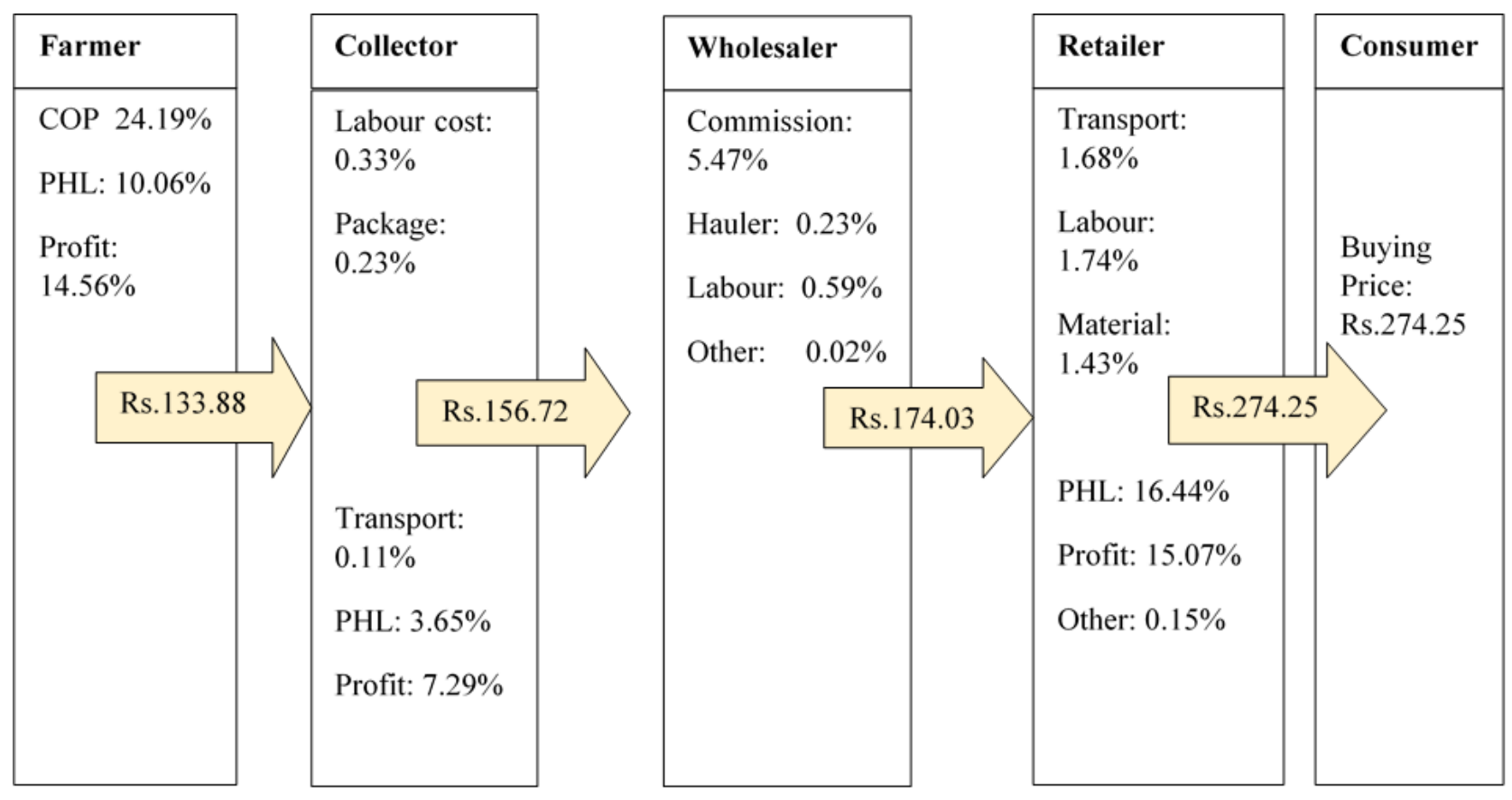

Figure 04: Final price formation of Capsicum Crop

The final price of capsicum is determining via primary vegetable supply chain which exists farmer, collector, wholesaler, and retailer (figure 04). At the famer level production cost, cost for the post-harvest losses and the farmer's profit were added to the primary price of Capsicum and it was about $48.81 \%$ by the final price (Rs.133.88). At the collector level, labor cost, material cost, transportation cost, post-harvest losses and collector's profit were added to the price of Capsicum and it was $11.61 \%$ by the total price (Rs.156.72), at the whole seller level $6.31 \%$ added to the final price (Rs.174.03) and it was contributed by wholesaler commission, hauler fee, labor cost and other costs as building rent, electricity bill, water bill, telephone bills at the retailer level $21.51 \%$ added to the final price (Rs.274.25) by the total cost of transport, labor, packing materials, post-harvest loses, other costs and retailer level profit 


\subsubsection{Brinjal}

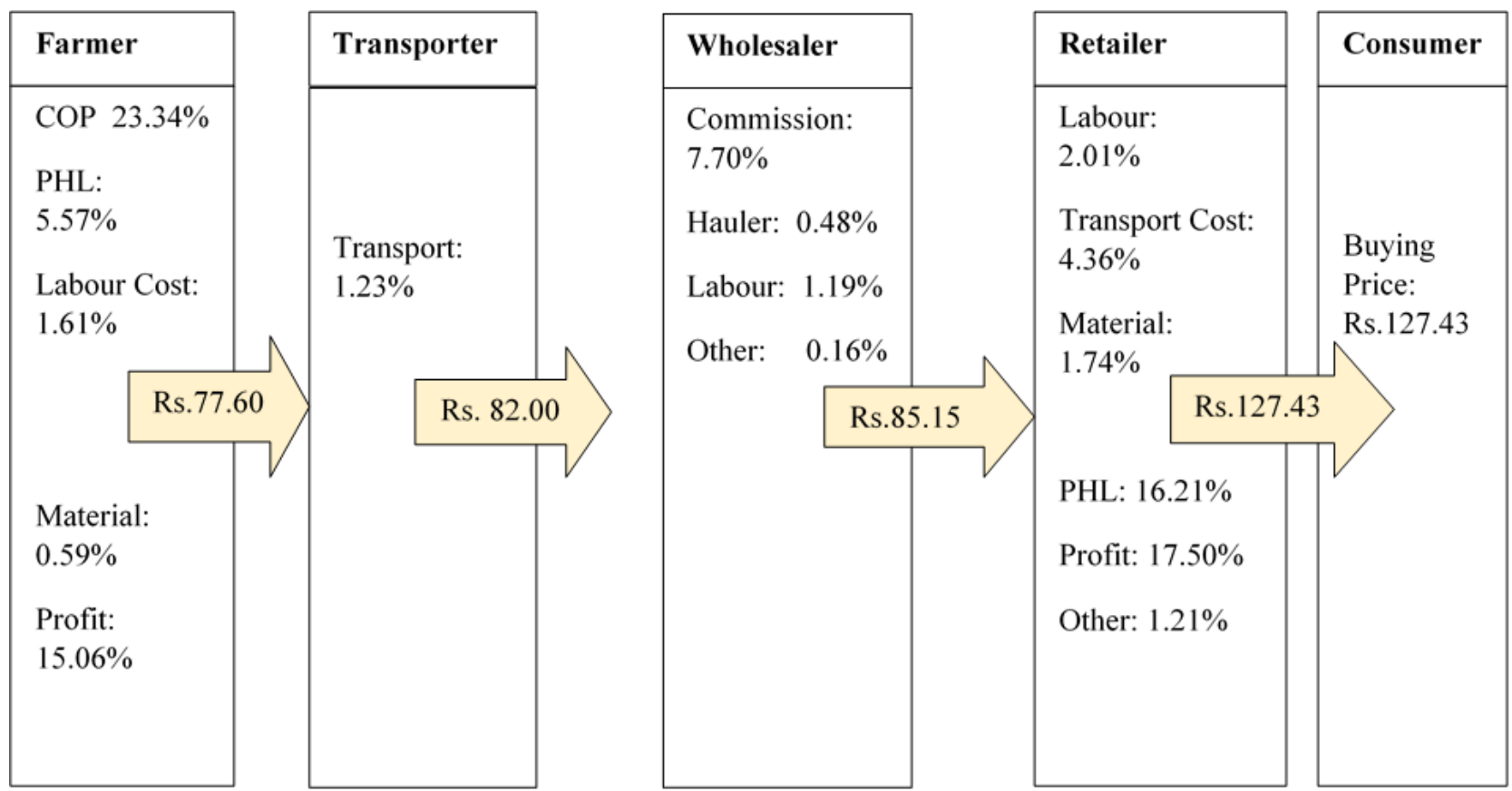

Figure 05: Final price formation of Brinjal Crop

The final price of Brinjal is determined via primary vegetable supply chain which exists Farmer, Transporter, Wholesaler and Retailer (figure 05). At the famer level production cost, cost for the post-harvest losses and the farmer's profit, labor cost, material cost was added to the primary price of Brinjal and it was about $46.17 \%$ by the final price (Rs.77.60). At the transporter level, transportation cost to the price of Brinjal and it was $1.23 \%$ by the total price (Rs.82.00), at the whole seller level 9.53\% added to the final price (Rs.85.15) and it was contributed by wholesaler commission, hauler fee, labor cost and other costs as building rent, electricity bill, water bill, telephone bills at the retailer level $43.03 \%$ added to the final price (Rs.127.43) by the total cost of transport, labor, packing materials, post-harvest loses, other costs and retailer level profit. 


\subsubsection{Beans}

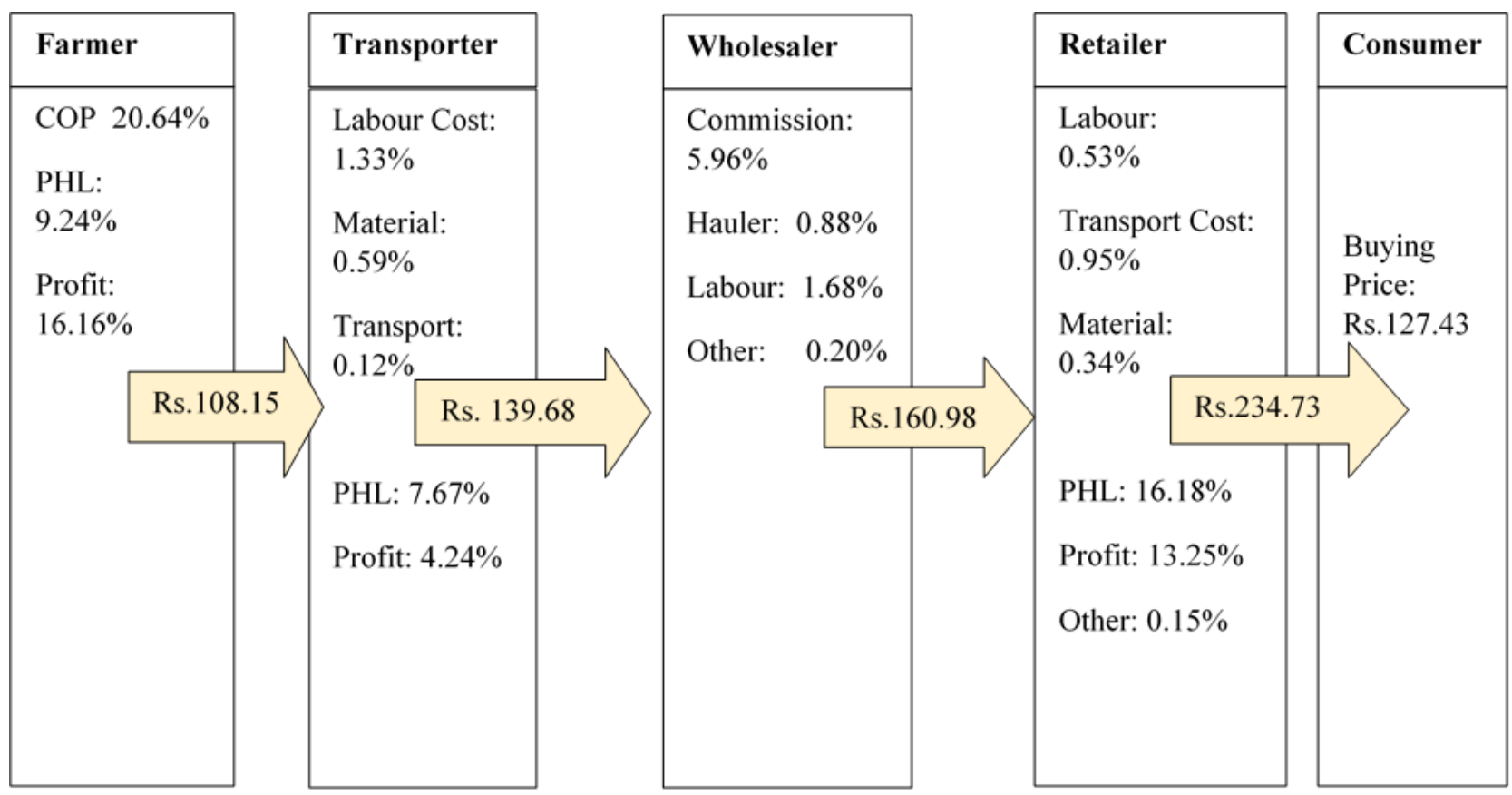

Figure 06: Final price formation of Beans Crop

The final price of Beans is determining via primary vegetable supply chain which exists farmer, collector, wholesaler and retailer (figure 06). At the famer level production cost, cost for the post-harvest losses and the farmer's profit were added to the primary price of Beans and it was about $46.04 \%$ by the final price (Rs.108.15). At the collector level, laborcost, material cost, transportation cost, post-harvest losses and collector's profit were added to the price of Beans and it was $13.95 \%$ by the total price(Rs.139.68), at the whole seller level $8.72 \%$ added to the final price(Rs.160.98) and it was contributed by wholesaler commission, hauler fee, labor cost and other costs as building rent, electricity bill, water bill, telephone bills at the retailer level $46.53 \%$ added to the final price(Rs.124.6) by the total cost of transport, labour, packing materials, post-harvest loses, other costs and retailer level profit. 
International Journal of Agriculture and Environmental Research

ISSN: 2455-6939

Volume: 07, Issue: 03 "May-June 2021"

\subsubsection{Pumpkin}

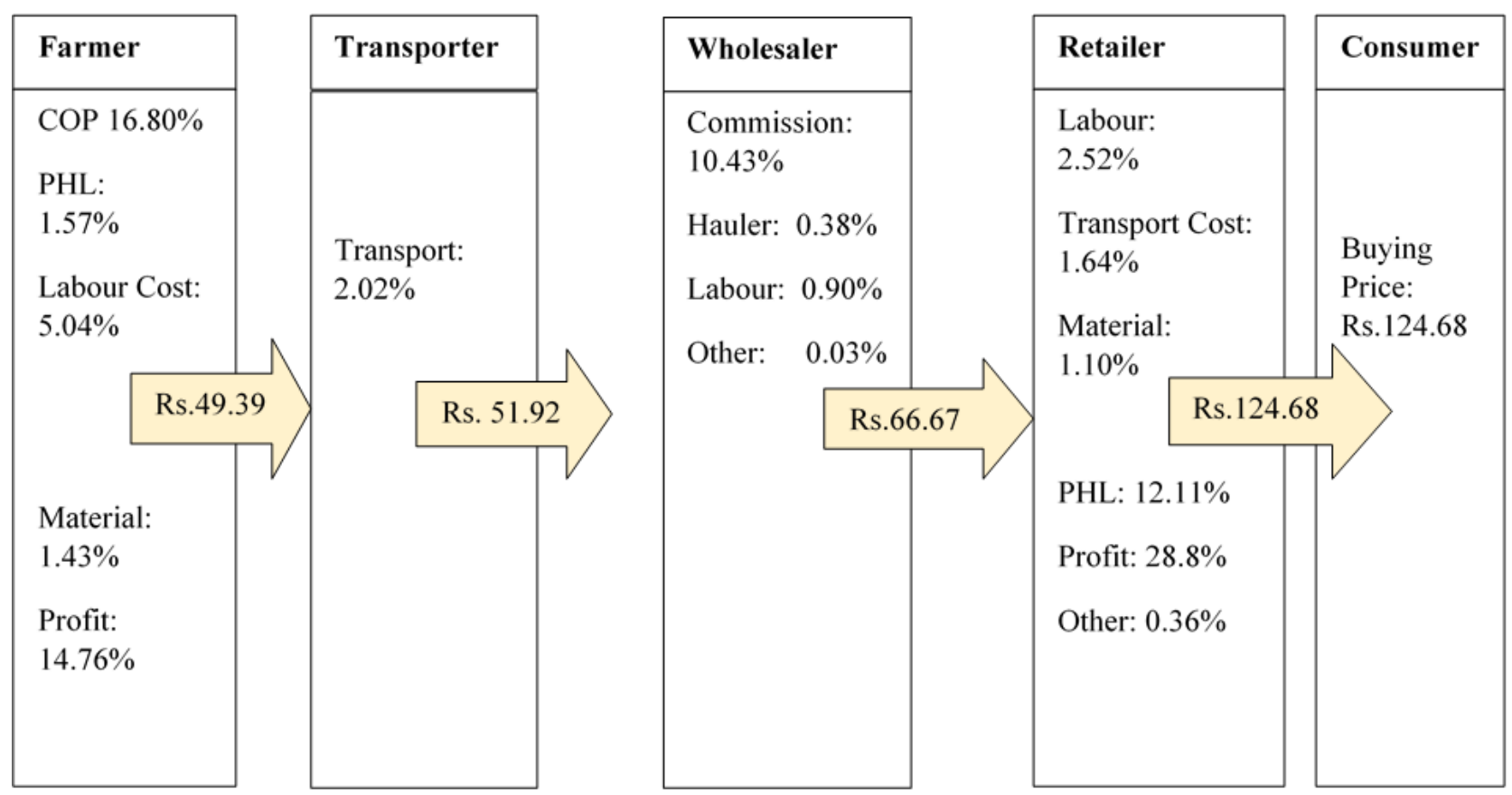

Figure 07: Final price formation of Pumpkin Crop

The final price of Pumpkin is determining via primary vegetable supply chain which exists farmer, transporter, wholesaler and retailer (figure 07). At the famer level production cost, cost for the post-harvest losses and the farmer's profit, laborcost, material cost was added to the primary price of Pumpkin and it was about $39.6 \%$ by the final price (Rs.49.39). At the transporter level, transportation cost to the price of Pumpkin and it was $2.02 \%$ by the total price(Rs.51.92), at the whole seller level $14.71 \%$ added to the final price (Rs.66.67) and it was contributed by wholesaler commission, hauler fee, labor cost and other costs as building rent, electricity bill, water bill, telephone bills at the retailer level $46.53 \%$ added to the final price(Rs.124.60) by the total cost of transport, labor, packing materials, post-harvest loses, other costs and retailer level profit.

\subsection{DISCUSSION}

Results show that there is a significant influence on vegetable supply chain segments to the price gap between the farmer and Consumer. Vegetable supply chain prone to have high influence on various segments and sources that engaged in moving vegetables from farmer to final consumer (Gunatilake, et al., 1992). Moreover, it has an irreversible impact on the performance of marketing channels in different ways (Kuruppu, 2007). 
International Journal of Agriculture and Environmental Research

ISSN: $2455-6939$

Volume: 07, Issue: 03 "May-June 2021"

In Sri Lanka, it is identified that traditional vegetable supply chain subjected to various inefficiencies due to many causes, as that the farmers who are in vegetable producing areas were unable to attract competitive buyers because of the under development of infrastructural facilities, some producers are in isolated areas. This cause lack of proper access to competitive market, further traditional vegetable supply chain contains of larger number of intermediaries between producer and consumer which encouraged comparatively high market margin. This resulted of given that less price for the producers while having higher market price for consumers (Esham and Usami, 2006, Gunatilaka, 2001, Rupasena, 1999, Vidanapathirana, 2008, Weerahewa and Kodithuwakku, 2004).

There are three main factors which were identified as particular importance to strengthen market linkages in Sri Lanka; such as improving rural road infrastructure, improving farmer coordination to aggregate volumes to exploit economies of scale and facilitate integration with agribusinesses and strengthening market information systems, including establishment of commodity exchanges Dixie (2007).

There were some studies which concluded the possibility of increasing efficiency between producer markets and consumer markets in the country (Gunatilaka, 2001). Ravichandran (2002) in his study on vegetable value chain in Sri Lanka concludes that a higher level of pricing efficiency is observed in the vegetable market and concludes that the markets in the producer areas and consumer areas are well integrated. Similarly, producer share varies from $30-45$ percent for different types of vegetable supply chains with respect to the performance measurements of the stakeholders (Dixie, 2007, Ravichandran, 2002, Rupasena, 1999, Vidanapathirana, 2008).

When considering the retailer margin, (Vidanapathirana, 2008) Vidanapathirana (2008) found that the retail margins range from of 65-70 percent to 35 percent and that the margins are either stagnant or marginally increasing over the years and do not show any signs of decline over the years. While (Dixie, 2007) concludes that the retail margins are around 31 percent, Further, (Gulati, 2010) identified that the strategic importance of knowledge and information in the supply-chain and such trainings as an intervention into value chain development and that this is a critical factor in implementing wider market change.

It is also found that modern retailing is increasingly dominating the international and local markets in fruits and vegetables and set standards for quality and safety in the sector. (Karim and Biswas, 2016) categorized market intermediaries' activities between farmer and consumer as value added activities, non-value-added activities, and necessary non-value-added activities. Among them $64 \%$ of non-value activities are as redundant. And this redundant activity causes for the price raises of the product price. The rise of supermarkets in most countries has resulted 
International Journal of Agriculture and Environmental Research

ISSN: 2455-6939

Volume: 07, Issue: 03 "May-June 2021"

in the establishment of centralized buying and distribution centres (Kuruppu, 2007, Weerahewa and Kodithuwakku, 2004). Further, Efficient management of supply chains and closer coordination from the farm gate to the consumer will have a strong influence on the future welfare of the consumer and everyone else involved in the fresh produce industry in Sri Lanka.

\subsection{CONCLUSIONS}

This study has analyzed vegetable supply chain by focusing on Carrot, Beetroot, Beans, Capsicum, Brinjal and Pumpkin in Sri Lanka. The study was addressed to identify the cost factors and their contribution towards the consumer price, to determine key factors which affect the price transmission along the supply chain of the selected vegetables and to identify potential factors to be controlled and increasing efficiency along the supply chain. Cost factors vary among the supply chain between actors. At each step of a supply chain, the cost is added to the product and it leads to increase the price consequently. As it is an inefficient and long chain of market intermediary cause's price increase dramatically from farmer to consumer. Significant factors which affect for the vegetable supply chain were cost of production, cost for the labour, packaging cost, post-harvest loss, profit at each stage, commission, hauler fee, transport and other cost as electricity, water, telephone and building rent. Cost of production and post-harvest losses being the highly contributing cost factors throughout the chain. At each stage nearby each factors observed the post-harvest losses.

\subsection{RECOMMENDATIONS}

The findings of this study enabled us to make the following recommendations for policy makers, developments actors and researchers who have strong interest in promoting vegetables production and marketing for equal benefits among value chain actors.

- Advances in harvest and post -harvest technology should be communicated to all stakeholder segments in vegetable supply chain

- $\quad$ The total cost of the farmers is much higher than the logistic cost due to increasing costs of raw materials, as fertilizer and insecticides, using low-cost technologies and recommended amount of fertilizer and insecticides will help to reduce this cost

- $\quad$ Establishment of vegetable supply chain with a smaller number of stakeholders

\section{REFERENCES}

[1]. Dixie, G., "Production Resources in Lagging Regions". In: Bank., O. K. R. T. W., (Ed.).2007.

[2]. Economics, T., "Sri Lanka GDP". 2019. 
[3]. Esham, M. and Usami, K., "Procurement behavior of the fruit and vegetable industry in Sri Lanka". Journal of Agricultural Sciences-Sri Lanka 2. 2006.

[4]. Gulati, A., Roy, G., Ganesh -Kumar, A., "Liberalizing Food Grains Markets" . Oxford University Press. 2010.

[5]. Gunatilaka, R., "Trends in Real Producer Prices and Agricultural Market Integration in Central Province", Sri Lanka. Poverty Impact Monitoring Unit, 2001.

[6]. Gunatilake, G., Perera, M., Wanigaratne, R., Fernando, R., Lakshman, W., Chandrasiri, J., and Wanigaratne, R.,"Rural poverty in Sri Lanka: priority issues and policy measures". Asian Development Review 10, 164-198.1992.

[7]. HARTI, "Weekly market analysis. Food policy and Agri-business Division", Hector Kobbakaduwa Agriculture Research and Training Institute.2019.

[8]. Huchet-Bourdon, M., "Agricultural commodity price volatility: an overview".2011.

[9]. Information, W. B., Technologies, C., and info Dev, "Information and communications for development 2012: Maximizing mobile". World Bank Publications.2012.

[10]. Karim, R. and Biswas, J., "Value stream analysis of vegetable supply chain in Bangladesh: a case study". International Journal of Managing Value and Supply Chains 7, 41-60.2016.

[11]. Kuruppu, J.,"Linking Small Holder farmers to Supermarket chains: The Cargills Model", Cornell University International Symposium on Agricultural Education and Information Systems, Zambia.2007.

[12]. Matthews, A., "Perspectives on addressing market instability and income risk for farmers". Joint AES and SFER conference on The Common Agricultural policy post 2013, 2010.

[13]. Ravichandran, T., "Efficiency of the Marketing System for Selected Vegetables in Sri Lanka".2002.

[14]. Rupasena, L., "Production and marketing of vegetables". Hector Kobbekaduwa Agrarian Research and Training Institute.1999.

[15]. Vidanapathirana, R., "Marketing margins of the domestic vegetable trade in Sri Lanka".2008.

[16]. Weerahewa, J. and Kodithuwakku, S.,"Evolution of food retail chains in Sri Lanka". International Food Policy Research Institute, Washington DC.2004. 